\title{
The Power to Tax, 33 Years Later
}

\author{
Jonathan Pincus ${ }^{1}$
}

\section{Abstract}

The basic puzzle about the power to tax is how to limit the capacity of government to exploit taxpayers, while at the same time not overly hampering the government in going about its useful activities. Standard economics fondly believes that it is giving advice to benevolent despots as to how to collect a given target of tax revenue at the least possible harm to the size of the economic pie. The Constitutional Political Economy approach of Geoff Brennan and Jim Buchanan showed that that very same advice is exactly what the non-benevolent government wants to hear in its efforts to maximise tax revenue. Brennan and Buchanan were concerned about excessive exploitation of taxpayers in the large; standard economics is concerned with secondorder small triangles of economic inefficiency; government is concerned about the size of first-order revenue rectangles: and so should we be.

'Good intentions will always be pleaded, for every assumption of authority. It is hardly too strong to say that the Constitution was made to guard the people against the dangers of good intentions. There are men in all ages who mean to govern well, but they mean to govern. They promise to be good masters, but they mean to be masters.'

Daniel Webster, American politician and diplomat (1782-1852)

The standard economic approach to taxation is to give advice to a benevolent despot. Courtesy of a referee, here is what motivates a benevolent government:

A benevolent politician seeks revenue (or a transfer of resources from the private sector) to establish and monitor property rights for the market sector, fund public goods and correct other market failures, and to achieve society's equity goals via direct income transfers, progressive income taxation and the provision of some goods and services at below

\footnotetext{
1 The University of Adelaide; jjpincus@gmail.com. Thanks, but no blame, go to Geoff Brennan, Henry Ergas and the referees. An earlier version was given at a conference - 'Freedom to Choose 2013: the economics of government failure', at the University of Notre Dame, Fremantle, sponsored by the Mannkal Foundation. The opinions are my own.
} 
cost. The benevolent politician/economist, in assessing the scale of taxation and expenditure, seeks to balance the marginal social cost of any tax used with the marginal social benefits of any item of expenditure. The total of taxation is the result of this balancing.

In the standard theory of public finance, the predominant form of benevolence is utilitarian, which involves a trade-off between redistribution and the aggregate size of the economic pie. Less commonly, the standard theory is cast in Paretian terms: the benevolent ruler is only concerned with efficiency with which the revenue target is reached (for example, Battaglini and Coate 2008). When it comes to taxation, in both cases the benevolent politician's objective is to meet a target of tax revenue while doing the minimum harm to the economy. The standard approach worries about the efficiency of the tax system; that is, it is concerned with excess burden triangles.

In 1980, Geoffrey Brennan and James Buchanan published The Power to Tax: Analytical Foundations of a Fiscal Constitution. Their book was directed at the intelligent citizen and not at a benevolent despot. Brennan and Buchanan assumed that the state acted selfishly, and spent on things that the rulers wanted, and not necessarily what the citizen wanted. A monopolist wants to gather in as much revenue as it can for its own purposes. Brennan and Buchanan applied the name 'Leviathan' to a state that did the same - that is, the Leviathan state engrosses as much revenue as it can for its own purposes.

Brennan and Buchanan acknowledged that their Leviathan is not a fully realistic description of government in the developed world - in part, because many countries, including Australia, have constitutional provisions and conventions that constrain the Leviathan-like tendencies of the state. In mainstream economics, these constitutional provisions and conventions are regarded as unfortunate, because they prevent benevolent governments from achieving the best of all possible outcomes for their citizens. In contrast, from the Brennan and Buchanan viewpoint, these constitutional provisions and conventions prevent non-benevolent governments from exploiting their citizenry to the full. Brennan and Buchanan's objectives in writing The Power to Tax were to understand the political economy of these kinds of constitutional provisions and conventions, to assess their effectiveness and to canvass additions and modifications. ${ }^{2}$

Brennan and Buchanan's book was analytical and did not provide a short description of what motivates a Leviathan government/politician. However, if it had, maybe it would run something like this:

2 The recently launched campaign of the Centre for Independent Studies, to limit tax revenues to 30 per cent of GDP, has a similar concern - to restrain the state within reasonable macro-economic limits so as to prevent government from excessive exploitation of taxpayers generally. 
In a democracy, governments gain power via complex majoritarian processes. Because the probability is trivial that your vote will affect the electoral outcome, voting is mainly an expressive act: expressing support of those who support your interests and values. Governments provide some public goods, but mostly provide benefits to particular segments of the population through laws and regulations, and though government transfers and final expenditures; and distribute burdens, including by taxation. Decisions about government spending and taxing are made on many grounds, including serving the interests of sections of the population who reward government in return, and who may engage in expenditure-seeking and tax-diverting activity. Government decisions are made within a polyarchy, and not by a single mind applying calculus to maximise a social welfare function. One government cannot commit the next. The Leviathan politician seeks to balance the marginal political and personal cost of taxation with the marginal political and personal benefits of a range of specific expenditure items or categories. These costs and benefits may be extrinsic or intrinsic, ideological or material. Total taxation very likely exceeds what a benevolent ruler would choose.

\section{The benevolent despot liveth}

In 1986, six years after the publication of The Power to Tax, Buchanan won the Nobel Prize for helping establish and nurture the intellectual fields of 'public choice' theory and 'constitutional political economy'. Therefore, you may well expect to see, in any serious study of tax theory, a reference to The Power to Tax and to its arguments.

Do not hold your breath.

In 2008, the superb tax economist Louis Kaplow published The Theory of Taxation and Public Economics. Kaplow never referred to The Power to Tax; moreover, he did not even acknowledge that there was any need to discuss what Buchanan called 'the structure within which political decisions are made'. Instead, Kaplow proffered his policy advice to a benevolent despot.

More recently Robin Boadway, a top theorist in the field of public economics, published a book entitled From Optimal Tax Theory to Tax Policy. It is meant to offer theory-based but practical advice to government. Boadway explicitly based his recommendations on the assumption that tax policy is run by a beneficent 
social planner with an unchallenged ability to commit future governments when it came to tax policy: to assume otherwise would be to stifle the usefulness of his analysis (Boadway 2012: 239). ${ }^{3}$

Mention should also be made of a major recent study of the UK tax system, commissioned by the Institute for Fiscal Studies in London. It was conducted under the direction of the Nobel Prize winner James Mirrlees (2010; 2011). In their reports, Mirrlees and colleagues decided not to take any account of the possible failure of government to act benevolently. This led the prominent Harvard economist Martin Feldstein (2012: 782) to remark that the Mirrlees Review contains no discussion of 'the political legitimacy of unlimited redistribution'. 'What kind of nation', Feldstein asked, 'places no value on the welfare of those with income in the top tax bracket, treating them only as the revenue producing property of the state?'

But to regard individual people as merely 'the revenue producing property of the state' is not specifically a 'British disease'. Front and centre of the Australian Treasury's (2012) presentation of self, in its 'Strategic Framework', is a statement entitled The Wellbeing of the Australian People. It is redolent with the presumption - seemingly pervasive at Treasury - that all incomes and assets are 'the community's', so that, if something is left in private hands, then it is only by the grace and favour of government or through government's incapacity to devise mechanisms that better achieve its goals while leaving less as the private income of the taxpayer.

In a speech about the 'wellbeing framework', senior Treasury official David Gruen (2011) remarked: 'We [in Treasury] of course see rewarding effort and risk as important from an efficiency perspective, but for that reason only.' Gruen's reference to 'efficiency' may comfort readers used to thinking in Paretian terms. However, that comfort is unjustified: the words 'economic efficiency' or close synonyms do not appear in the 'wellbeing framework'. Rather, one of the main purposes of the framework clearly seems to be to attempt to protect Treasury from the claim that it continues to place too much emphasis on economic efficiency (Pincus, forthcoming). Certainly, there is no hint in the framework (or, from what I have seen, in senior Treasury speeches) of concern that taxation is too high. Rather, Treasury Secretary Martin Parkinson has expressed anxiety that taxation is too low to fund government spending.

Treasury has travelled a long way from the time when, it is claimed, the then Secretary opposed the introduction of a goods and services tax on the

3 'Optimal tax research in the spirit of Mirrlees (1971) has generally avoided situations in which the Revelation Principle does not apply, such as if the social planner cannot commit to a future policy plan' (Mankiw, Weinzierl and Yagan 2009: n.3). 
grounds that it was so much more efficient than the taxes it was to displace that, inevitably, it would lead to an increase in government revenue and, therefore, even more wasteful spending.

\section{Tax theory in orthodox public finance}

Standard economic theory of taxation says if it cannot move, then tax it hard; but if it can easily move (or change) to avoid the tax, then tax it lightly. Thus, the state should place a heavier tax on entities that find it hard to avoid some of the tax by fleeing the jurisdiction; on activities that do not have close, untaxed or lightly taxed substitutes; on characteristics of the taxpayer that are costly or slow to alter. (I leave it to the reader to construct the contra-positive statements.)

Let me illustrate. Gordon Tullock, then a famous economist, stayed with me in Canberra for a few days in 1974. At one of his talks, Tullock said that it was only when he noticed that Jonathan Pincus was doing his own brick paving, that he came to appreciate just how high were the marginal tax rates of the Australian income tax schedule. Jonathan had to earn an extra 4000 dollars in order to retain 1000 post-tax dollars with which to pay someone to do his paving: the marginal tax rate was 75 per cent. Therefore, said Tullock, Pincus found it worthwhile to do his own paving, even though his comparative advantage lay in economics, not in laying paving.

The high marginal tax rates encouraged people into do-it-yourself activities, which were tax-free; to this extent, the high marginal tax rates on those with high earning ability reduced the size of the monetised or 'market' economy and, therefore, reduced the taxable capacity of Australia. So, if you were advising benevolent government how to collect the required amount of tax revenue, your advice would be to tax income less heavily. Something like Milton Friedman's 'negative income tax' schedule seems to be approximately optimal, with a large 'demogrant' and a flat marginal rate schedule (see Mankiw, Weinzierl and Yagan 2009).

But what should be put in its place? Here standard economics advocates heavier taxes on natural resources and land, neither of which can move in response to taxes. High resource and land taxes would harm the economy less than would high marginal income tax rates.

But say you were advising a Leviathan government, keen to maximise its tax take. Again, you would advise against very high tax rates on incomes - avoid the backward-bending part of the Laffer curve. Rather better to cut those rates and increase and broaden the taxes on land and other natural resources. 
Colbert, in the seventeenth century, saw the problem from both sides, when he allegedly said: 'The art of taxation consists in so plucking the goose as to obtain the largest possible amount of feathers with the smallest possible amount of hissing.'

Standard economics aims to minimise the hissing for a desired amount of feather; but the same tax rules would produce the maximum amount of feathers for a given amount of hissing. Brennan and Buchanan argued that their analysis leads to the conclusion that there would be more feathers (tax) and more hissing (burden) under Leviathan than under a benevolent ruler; yet both would follow the same kind of rules of tax design.

Mainstream economists like Mirrlees, Boadway and Kaplow fondly think that they are giving advice to a benevolent despot. The brilliant insight that Brennan and Buchanan brought to bear in The Power to Tax was that Mirrlees and Co are unknowingly giving exactly the advice that the Leviathan seeks: how to gain the maximum in tax revenue.

To show this requires two steps.

Firstly, the tax rates that Mirrlees and Co derive for a system of 'optimal taxation' are the very same tax rates to achieve largest tax revenue compatible with given a pre-specified amount of harm being caused to the economy by the taxation. In mathematical terms, the two optimising problems are duals. ${ }^{4}$ Even worse, the Leviathan is not worried about maximising revenue for a given, pre-specified amount of harm to the economy. No, the Leviathan wants the maximum flow of revenue: he is a despot, and in for the long term, even if the political complexion of government changes periodically.

At this point comes the second step: the general tax rules that standard theory derive for a system of 'optimal taxation' are the very same rules that the Leviathan would apply: high tax rates on land and resources and other things that find it hard to escape the tax; lighter rates on fugitive tax bases. The rates would be higher and the quantity of tax revenue greater than if the marginal social-welfare calculus set a constraint on the amount of harm caused to the economy. But the general pattern of tax rates would be just as standard theory prescribes.

\footnotetext{
4 The same equimarginal conditions arise from the following two problems: $\min B(\tau 1, \tau 2, \tau 3$, ...) s.t. $R(\tau 1, \tau 2, \tau 3, \ldots)=R^{*}$, and max $R(\tau 1, \tau 2, \tau 3, \ldots)$ s.t. $B(\tau 1, \tau 2, \tau 3, \ldots)=B^{*}$, where $B$ is burden, $B^{*}$ is any given burden target, $R$ is revenue, $R^{*}$ is a revenue target, and $\tau i$ are the tax rates. The Benevolent ruler, using a social welfare function, maximises welfare by altering the budget size and composition until the shadow price (or cost) of additional revenue from any source equals the shadow price (or benefit) of additional spending of any type. The Leviathan rulers select that quantum of taxation at which the Leviathan's own marginal benefit equals the Leviathan's own marginal cost.
} 
By proffering tax policy advice to benevolent rulers, unknowingly Mirrlees and Co were giving advice to the revenue-seeking Leviathan. For many decades, Mirrlees used his magnificent intellectual power to assist government to pluck more feathers with less hissing. He devoted no effort at all to advising citizens about how to stay the hand of the pluckers.

Even if, on moral or merely practical grounds, it were the case that all income and wealth 'belongs to the community', then it would still be sensible for 'the community' to take precautions against the possibility that governments tax and spend too much, and leave too little for private disposition.

\section{Taxation of mining ${ }^{5}$}

In my opinion the standard theory of public finance was offered in support of a tax on pure rent, which would have garnered modest revenues from the mining industry; and that the theory was used by government to justify a tax that would, in fact, have fallen mostly on quasi-rents, and which would have gathered huge revenues.

This effort drew support from a range of mainstream economists.

Dr Ken Henry, then Secretary of Treasury, chaired the last major review of the Australian tax system (Treasury 2010). In keeping with standard public finance economics, the review recommended lower taxes on personal and company incomes, the abolition of mining royalties, and the introduction of a new tax on mining rents.

By definition, a pure rent is any payment made to a factor of production that is not needed to bring it into the existence and is not needed to cause it to be supplied as a factor of production. A quasi-rent is a payment made to an alreadyexisting factor, and in excess of what would be needed to elicit its supply of productive services. Therefore, a tax on pure rents does not alter the quantity supplied of the taxed objects or services; however, a tax on quasi-rents can alter the future supply of the taxed factors of production.

A tax on pure rents is the economist's version of the magic pudding or the perpetual motion machine: it is a tax that generates revenue but imposes no excess burden on the economy. However, its support is an incomplete theory, one that ignores information asymmetry of the kind emphasised by Mirrlees in his work on optimal income tax schedules (beginning with Mirrlees 1971), as well as Laffont and Tirole (1983) on regulation, and which bedevils actual

5 This section draws freely on Ergas, Harrison and Pincus (2010), where it is argued that no actual tax can produce revenue without any incentive effects on the parties liable to the tax. 
attempts to tax pure rents; ${ }^{6}$ and it is a theory that ignores that there is a limited supply of the talent and knowhow, of the kind needed to access the full value of rents from minerals in the ground. Be that as it may, to recommend taxes on pure rents is in keeping with standard theory of public finance.

The new tax proposed by Dr Henry became the Resource Super Profits Tax, RSPT, projected to produce many billions: at that time, the government was desperately short of revenue. But the Resource Super Profits Tax elicited too much hissing, which helped to bring the first Rudd government to a sudden end. The Rudd \#1 government was too unconstrained in its tax ambitions. Instead of the RSPT, the Gillard government imposed the Minerals Resource Rent Tax. Less hissing, but virtually no feathers - the MRRT was negotiated with the large established miners, and has produced almost nothing by way of revenue in its very short life so far.

The Resource Super Profits Tax, the Rudd \#1 tax, was excessively exploitative - it was a clear case of government failure in the tax arena. The Minerals Resource Rent Tax, the Gillard tax, in contrast, represents a sensible compromise between the exploitation of property owners, and the need for public revenue. Although it has serious flaws and was oversold, the MRRT is not a clear case of government failure in the tax arena.

Dr Henry claimed that economic theory of the 'Brown' tax told him that a tax rate of 60 per cent, even 90 per cent, would not lead to any diminution of mining in Australia. He must have had in mind a tax on pure rents. Ministers and Treasury officials analogised the RSPT to a government taking a form of equity in mining ventures, and paying for it, as it were, with a promise of covering 40 per cent of any costs, including losses (the latter covered by the issuance of government promissory notes, bearing interest at the long-term bond rate). ${ }^{7}$

This could be a reasonable representation for new ventures (subject to how costs are defined and measured, and ignoring questions of asymmetrical information that bedevils attempts to tax rents, as well as questions of the supply of mining talent and knowhow). Via the RSPT, the government becomes an equity partner in an uncertain prospect. The history of these projects, for good or bad, lies in the future. When the RSPT was applied to mining ventures initiated after the imposition of the tax, it was reasonable to claim that the purpose of the RSPT was the taxing of pure rents, and pure rents only. Realistically, this source of RSPT revenue would have been small, delayed and uncertain. (Some prominent tax economists advocate a version of the super profits tax for all industries.)

6 Dasgupta and Heal (1979) derive the expression for a resource royalty that captures all of the pure rent. Its implementation requires that the taxing authority knows the supply or cost function of the miner.

7 Company tax is to be paid on profits net of RSPT payments. 
However, the analogy between the RSPT and taking an equity punt does not work for existing ventures. Part of the history of an existing project has happened. Government would not have been taking its share of what came along, the good times and the bad. Rather, the first Rudd government wanted to impose the tax following and in response to a series of years of high and rising mineral prices; that is, when times were spectacularly good. For existing projects, this retrospectivity means that government avoided bearing the threat of losses that it would have borne in an actuarially neutral (that is, fair) bet. Most of the RSPT revenue would have come from quasi-rents, not from pure rents. Realistically, this source of RSPT revenue would have been large, soon and relatively certain.

I repeat one of the two rules of standard economics: tax heavily if the taxed activity or object cannot easily evade or avoid. When these two taxes were introduced, the mining companies had invested many tens of billions into mining in Australia. Their investments were sunk, literally in many instances they could not be packed up and shipped cheaply to another country. They were just standing there, ready to be plucked, according to mainstream economics: tax revenue would have been large and, depending on the reaction of investors in mining and generally, the excess burden relatively small.

The MRRT, which applies to iron ore, coal, and coal seam gas, has a nominal 22.5 per cent tax rate applied to cash flow less an allowance for capital costs, with any negative cash flow carried forward at the long-term bond rate plus seven percentage points. Existing mines were able to set their initial capital at market valuation, and so the element of taxation of quasi-rents, such a feature of the RSPT, is largely absent. ${ }^{8}$ Rather, the Minerals Resource Rent Tax is primarily levied on the profits of future investments in mining, not past investments.

It is one thing to impose a rent tax prospectively, which is what the Minerals Resource Rent Tax does - then any project that pays the tax is a project that commenced after the tax was imposed. It is quite another thing to impose the RSPT retrospectively on existing projects, as the first Rudd government intended to do.

The Australian constitution requires the federal government to pay just or fair compensation for property taken by government. ${ }^{9}$ This contradicts standard economics - if it is natural or exogenous capital and it cannot flee, then tax it very hard, even at 100 per cent; if it is produced capital, then, having regard

8 Presumably, the market valuations capitalised expected profits, net of taxes and royalties and, therefore, capitalised residual resource rents. Ergas, Harrison and Pincus (2010) argued, however, that the MRRT discriminates against risky projects; and discussed sovereign risk.

9 Section 51 xxvi: The acquisition of property on just terms from any State or person for any purpose in respect of which Parliament has power to make laws. 
for incentive effects, tax it heavily. The constitution's provision about fair compensation for property reflects a concern about exploitation by government and, moreover, about selective exploitation - only the miners were to pay the super-profits tax.

I am not arguing that no taxation is legitimate if it causes capital losses to anyone: that would rule out almost every tax, even a poll tax: people may leave the city or nation, if a severe enough poll tax were levied, but few would do so in response to the light poll tax that Margaret Thatcher imposed. But Mrs Thatcher learned that a poll tax also brings people out onto the street in protest, which helped to bring her down. ${ }^{10}$ The unpopularity of taxes seems to be in direct relationship to their approval rating from economists in the mainstream tradition.

My test is not that taxation should Do No Harm, but that taxation should make a reasonable compromise between exploiting or expropriating, one the one hand, and funding the useful activities of government, on the other hand. Taxes that take a sizeable share of the value of some long-lived assets, or the income or wealth of a small portion of the population, do not satisfy that vague test.

\section{A height tax}

In standard economics, the economics of the benevolent despot, the ideal tax base has two characteristics: it cannot be hidden; it is unchangeable. That is to say, the ideal tax base is easily observed and measured by the tax department, and it is difficult or impossible for the taxpayer to change its nature, size or location. Governments are keen to find and get access to tax bases that display these characteristics or come close.

In their search for revenue, governments have been well served by standard economics - many are the articles in leading economics journals advising governments along these lines. For example, James Mirrlees, mentioned earlier, won his Nobel Prize for his work on how governments should structure income tax scales in view of the fact that governments cannot directly observe the earning ability of a taxpayer, but only their actual earnings.

Recently, some economists have shown that taller people and better-looking people have higher earning capacities than shorter and less-beautiful people, all else being equal. This has led Mankiw and Weinzierl (2010) to discuss putting a

10 Mankiw, Weinzierl and Yagan (2009) remarked that 'As this [Thatcher's poll tax] episode suggests, the social planner has to come to grips with heterogeneity in taxpayers' ability to pay. If the planner could observe differences among taxpayers in inherent ability, the planner could again rely on lump-sum taxes, but now those lump-sum taxes would be contingent on ability.' 
higher tax on taller people. Such a tax is not likely to cause many tall people to have an operation to make them shorter; nor would a modest tax on handsome people cause many to have an uglifying operation.

Standard economic theory says that income earners react to an income tax by legally shifting effort away from taxable activities, into home production or leisure; and some evade the tax illegally. However, people with higher earnings capacity will respond less than other taxpayers: it is optimal for such people to work harder and take less leisure, than those with lower ability.

Of course, governments may well decide not to take the economist's advice, and not put on a heavier tax on taller or more handsome people. Given my family name, I hope no economist can convince government to act on evidence that Jews have a higher earning capacity than non-Jews.

Any government that seriously went down the path of taxing according to personal characteristics - a path that is being strewn by mainstream economists with tall, beautiful poppies - any such government would be headed for failure of a serious kind: excessive and discriminatory exploitation of specific classes of taxpayers. As Mankiw and Weinzierl suggest (2010: 12), democratic societies may have an interest in avoiding the taxation of specific groups as a matter of course to counter the majority's temptation to tax minority groups. The benevolent ruler of standard public finance theory suffers no such temptation.

But there is another concern, one that does not often occur to these tax theorists: offering a new and efficient tax base to government will lead to more tax revenue and to more government spending of a kind not justified by the marginal analysis of standard public finance theory.

\section{Conclusion}

One of the most important functions of government is to impose taxes, chiefly in order to finance public outlays. Governments fail if they fail to make a reasonable compromise between exploiting people and limiting economic freedom, on the one hand, and filling the coffers of Treasury, on the other. The Resource Super Profits Tax was a government failure, being too exploitative; the Minerals Resource Rent Tax has faults, but was not an instance of government failure.

In this paper, I have contrasted the standard economics of taxation with the Constitutional Political Economy approach offered by Geoff Brennan, Jim Buchanan and colleagues. Standard economics fondly believes that it is giving advice to benevolent despots, advice as to how to collect a given target of tax revenue at the least possible harm to the size of the economic pie. Brennan and 
Buchanan showed that in fact that very same advice, from standard economics, is exactly what the non-benevolent Leviathan government wants to hear in its efforts to maximise tax revenue.

Brennan and Buchanan worry about excessive exploitation of taxpayers in the large. Standard economics is concerned with the second-order small, with the triangles of economic inefficiency; government is much more concerned about the size of first-order revenue rectangles, and so should we be.

\section{References}

Battaglini, M. and Coate, S. 2008, 'Pareto efficient income taxation with stochastic abilities', Journal of Public Economics 92: 844-68.

Boadway, R. 2012, From optimal tax theory to tax policy: retrospective and prospective views, Cambridge, Mass: MIT Press.

Brennan, G. and Buchanan, James M. 1980, The power to tax: analytical foundations of a fiscal constitution, Cambridge U.K.: Cambridge University Press.

Dasgupta, P. and Heal, G. M. 1979, Economic theory and exhaustible resources, Welwyn Eng.: J. Nisbet; Cambridge, Eng.: Cambridge University Press.

Ergas, H., Harrison, M. and Pincus, J. 2010, 'Some economics of mining taxes', Economic Papers 29(4): 369-83.

Feldstein, M. 2012, 'The Mirrlees Review', Journal of Economic Literature 50(3): 781-90.

Gruen, D., Kelly, J., Gorecki, S. and Wong, T. 2011, 'Wellbeing, living standards, and their distribution'; at: http://archive.treasury.gov.au/documents/2153/ PDF/speech_dg_nz.pdf

Kaplow, L. 2008, The theory of taxation and public economics, Princeton, N.J. and Oxford: Princeton University Press.

Laffont, J. J. and Tirole, J. 1993, A theory of incentives in procurement and regulation, Cambridge, MA: MIT Press.

Mankiw, N. Gregory, Weinzierl, M. and Yagan, D. 2009, 'Optimal taxation in theory and practice', Journal of Economic Perspectives 23(4): 147-74. 
Mankiw, N. Gregory and Weinzierl, M. 2010, 'The Optimal Taxation of Height: A Case Study of Utilitarian Income Redistribution', American Economic Journal: Economic Policy 2(1): 155-76.

Mirrlees, James A. 1971, An Exploration in the Theory of Optimal Income Taxation,' Review of Economic Studies 38: 175-208.

Mirrlees, J., Adam, S., Besley, T., Blundell, R., Bond, S., Chote, R., Gammie, M., Johnson, P., Myles, G. and Poterba, J. (eds) 2010, Dimensions of Tax Design: the Mirrlees Review, Oxford: Oxford University Press.

- 2011, Tax by Design: the Mirrlees Review, Oxford: Oxford University Press.

Pincus, J. (forthcoming 2013), 'The Wellbeing of the Australian People: Comments on the Treasury's Framework' in Podger, A. and Trewin, D. (eds), Measuring and Promoting Wellbeing: How Important is Economic Growth? Essays in honour of Ian Castles AO and a selection of Castles papers, Canberra: ANU E Press.

Treasury 2010, 'Australia's Future Tax System. Report to the Treasurer', December 2009; at: http://taxreview.treasury.gov.au/content/Content.aspx?doc=html/ pubs_reports.htm (accessed 29 August 2012).

2012, 'Australian Treasury Strategic Framework 2012-13'; at: http:// www.treasury.gov.au/About-Treasury/OurDepartment/Treasury-StrategicFramework (accessed 11 November 2013). 